\title{
Symbolika v českých a polských somatických frazémech s lexémy sluch/stuch a ucho a jejich vzájemná ekvivalence
}

Dariusz Tkaczewski

\begin{abstract}
Symbolism in Czech and Polish Somatic Phraseological Units with Lexemes sluch/ stuch [hearing] and ucho [ear]] and their Mutual Equivalence

The use of names of senses and sense organs as a basic component of so-called somatisms, i.e. phraseological units referring to human (animal) body/organism and its functions has a long history which goes back to ancient times. As a linguist and a Slavic studies specialist, the author of this article examines the fact that such phraseological expressions exist in closely related languages and investigates the issue of their equivalence - their mutual translatability. Phraseological expressions play an essential role in the teaching of Czech or Polish and in the work of translators of these languages, since learning, active knowledge and awareness of the content of rich phraseology, which has great semantic significance, are equally important as the knowledge of the vocabulary. In the course of the investigation, the author of this article indicates the meaning, sense and symbolism of hearing and ear in world cultures, excerpts $61(7+54)$ Czech and Polish phrasemes and 6 proverbs containing these lexemes from available 'classic' dictionaries in which the particular sense sluch/stuch [hearing] and sense organ ucho [ear] make the main entry, orders and compares them in terms of equivalence, and presents the quantitative statistical data by means of three graphs.
\end{abstract}

\section{KEYWORDS}

Czech / Polish, lexemes sluch/stuch [hearing] and ucho [ear], symbolism, somatic phraseological units, mutual equivalence.

\section{KLÍčOVÁ SLOVA}

Čeština / polština, lexémy sluch/stuch a ucho, symbolika, somatické frazémy, vzájemná ekvivalence. 
Smysly ${ }^{1}$ a jejich orgány poskytují člověku základní kontakt s prostředím, jež ho obklopuje, nebo obecněji s vnějším světem, a slouží jeho orientaci v něm. Výkon a kvalita smyslů určují naši bezpečnost, ale především umožňují (obvykle kombinace jejich funkcí) komunikaci s okolním světem a dalšími lidmi tím, že přijímají interní (psychické) signály a prostřednictvím mozku, včetně nervové soustavy, interpretují široce chápané vnější (fyzické a psychické) znaky. Komunikace probíhá pomocí přirozeného jazyka, tudíž přijaté akustické signály jsou primární a mají zde prvořadý význam. $\mathrm{V}$ přirozených podmínkách je tento jev realizován pomocí sluchu a jeho orgánu - ucha.

Stejně jako ostatní smysly a jejich orgány (zrak/oko, hmat/kůže, chut'/jazyk, čich/nos), rovněž stuch/sluch a ucho se jako obecné pojmy a výrazy ve slovníku a v textu stávají významnými jazykovými znaky a nositeli důležitých kulturních a společenských symbolů. V kultuře Slovanů, tedy také Poláků a Čechů - národů s podobnými historickými a náboženskými tradicemi, které vyplývají z jejich sousedství a vztahu "genetické př́buznosti“ -, słuch/sluch a ucho mají roli takovýchto výrazných jazykových a kulturních znaků/symbolů. Je třeba poznamenat, že když se objevily v představách našich slovanských předků, často znamenaly pro každého uživatele jiné pojmy, předměty, ideje či víru. Jejich výskyt coby symbolů v současné polštině a češtině, jakož i v polské a české kultuře, se zdá být věčným a samozřejmým, živým a funkčním. Musíme mít však na paměti a být si vědomi skutečnosti, že pro každého průměrného Poláka nebo Čecha je význam těchto pojmenování nejednoznačný a mnohdy dokonce neurčitý. ${ }^{2}$

Když zkoumáme význam pojmů a slov słuch/sluch a ucho, je třeba primárně upozornit na lexikální sémantiku těchto slov a zároveň popsat základní, klasickou, nebo dokonce vzorovou či normativní symboliku smyslu sluchu [stuch] a ucha jako orgánu sluchu, která je obvykle odrazem dávné antické kultury nebo její stopou v našich slovanských národních kulturách - polský nebo český význam těchto slov se shoduje $s$ univerzálním, starověkým tradičním obsahem, který byl přijat ve většině evropských kultur a jazyků. Dříve než prozkoumáme

1) Ve světové ikonologii jsou smysly také označovány jako city [czucia] a jsou prezentovány jako postava představující mladého muže oblečeného v bilém, který má na hlavě rozprostřenou pavučinu, je obklopen dalšími postavami nebo spiše zviřecími symboly, tedy božstvy: Opicí, Supem, Kancem a Rysem, čili zvířaty, která mají ve všeobecném pojetí ve srovnání s člověkem jednotlivé smysly dokonalejší, vyostřené nebo subtilněǰ̌í (RIPA 2013: 241-242, 432; KOPALIŃSKI 2006: 216-218, 443-445).

2) Symbolika nejen zkoumaných lexémů je ve skutečnosti velmi bohatá a většinou může být její výklad neomezený nebo nejednoznačný. Tento článek kvůli svému formálnímu rámci prezentuje pouze symboliku základní. Podrobnou interpretací se zabývají vhodné zdroje, ke kterým jistě patří Słownik symboli [Slovník symbolů] Władysława Kopalińského (KOPALIŃSKI 2006) a Leksykon: znaki Świata, Omen, przesąd, znaczenie [Lexikon: znaky Světa, Omen, pověra, význam] Piotra Kowalského (KOWALSKI 1998). 
samotnou symboliku těchto dvou názvi̊, se musíme soustředit na jejich striktně lexikální význam a připomenout současné definice těchto lexémů z nejspolehlivějších zdrojů, tedy českého Slovníku spisovného jazyka českého a Velkého slovníku jazyka polského. $V$ tomto případě výrazy sluch [słuch] ${ }^{3}$ a $u c h o^{4}$ dnes mají konkrétnější slovníkový význam a smysl, ovšem za předpokladu, že definice nebudou prozatím obsahovat frazeologický kontext uvedený ve slovnících, který je nejčastěji založen na jazykovém korpusu. Výše uvedená souvislost je pro tento článek zcela zásadní a bude pojednána dále.

Sluch nebo slyšení uchem je ve starověkých bájích znázorněno jako býčí ucho, které pečlivě sleduje zvuky kolem sebe, protože kráva v řiji signalizuje tento stav hlasitým bučením, které někdy trvá několik hodin. Když se v tomto okamžiku neobjeví býk a nedojde tedy $\mathrm{k}$ páření, bude to možné znova až v budoucnu za stejné situace, protože jindy se kráva jakémukoliv kontaktu se samcem vyhýbá. $Z$ tohoto důvodu instinkt nutí býka pozorně naslouchat, aby zbytečně nepřišel o velmi očekávaný okamžik „záletư“. Druhým symbolem sluchu/slyšení je žena v doprovodu laní hrající na loutnu (RIPA 2013: 241, 432; KOPALIŃSKI 2006: 443-445; KOWALSKI 1998: 568-571).

Ucho v tradici středomořských kultur symbolizuje poslech a odposlouchávání, ale také interpersonální komunikaci, zvědavost a znalost, radu, poslušnost, stejně jako chybu, lichotku, pokušení, nebo dokonce zradu. Ve starých pohanských sakrálních budovách, na oltářích a stěnách se objevovaly uši nebo ucho božstva, symbolizující naslouchání modlitbě. Byly také považovány za votivní dary jako poděkování za vyléčení ušních onemocnění. V Bibli najdeme rovněž

3) Sluch [...] — „1. smysl, kterým se vnímá zvuk; orgán slyšení [...]; 2. kniž. slyšení, vyslechnutí [...]; 3. zast. zvěst, zpráva, slech [...]; 4. často mn. sluchy řidč. slechy (mysl.)“; Słuch — „1. zmysł, zdolność słyszenia; 2. s. muzyczny — zdolność rozpoznawania poszczególnych tonów melodii, poprawnego odtwarzania melodii i odróżniania poprawnego wykonania melodii od fałszu, słuch absolutny; 3. s. literacki — szczególna zdolność do czegoś; 4. (łow.) ucho zająca, królika, dzika; 5. (pot.) słuchy — niesprawdzone wiadomości gdzieś usłyszane."

(http://ssjc.ujc.cas.cz/search.php?hledej=Hledat\&heslo=sluch\&sti=EMPTY\&where=hesla\&hsubstr=no; http:// wsjp.pl/index.php?id hasla=24641\&ind=0\&w szukaj=s\%C5\%82uch\# [přístup: 10.09.2017])

4) Ucho [...] — „1. sluchový orgán; jeho vnější část; boltec [...]; 2. věc n. její část připomínající nějak ucho (boltec) [...]; 3. voj. slang. voják bez hodnosti, vojín; vojín nováček; expr. nezkušený člověk, začátečník vůbec [...]; 4. řidč. nadávka, zprav. neobratnému člověku [...] $\rightarrow$ zdrob. ouško v. t., ušíčko v. t.;" Ucho — 1. narząd słuchu, usytuowany w głowie parzysty narząd umożliwiający słyszenie, osłonięty z zewnątrz małżowiną (u. zewnętrzne, u. środkowe, u. wewnętrzne); 2. małżowina, część ciała osłaniająca wejście do ucha - narządu umożliwiającego słyszenie; 3. słuch, 4. metafora człowieka jako kogoś, kto słucha lub podsłuchuje (,gumowe ucho'); 5. część czapki lub innego nakrycia głowy, często ruchoma, służąca do osłaniania ucha; 6. uchwyt mający zwykle półkolisty kształt, 7. u. igły, otwór, przez który przewleka się nitkę lub sznurek; 8. u. w fortyfikacji, wysunięta, zwykle półokrągła część budowli obronnej, chroniąca przed ogniem ukośnym; 9. (pot.) pieróg, ekspresywnie o uszku - pierogu."

(http://ssjc.ujc.cas.cz/search.php?hledej=Hledat\&heslo=ucho\&sti=EMPTY\&where=hesla\&hsubstr=no; http:// wsjp.pl/do_druku.php?id hasla=24590\&id znaczenia=0 [přistup: 10.09.2017]) 
mnoho odkazů na ucho Boži. ${ }^{5}$ Duchovní slyšení znamená „vnitřní ucho“ v souvislosti s knězem, protože jenom on může mít podíl na obřadu sacrum jako lidský vyvolený a „božský agent“, tedy ten, který se může modlit a mluvit $s$ božstvem a přijímat od něj zprávy (včetně mlčení a ticha, které jsou podle teologů nejvyšší formou modlitby). Shodně se starozákonní tradicí se při předávání kněžské moci navlhčovala krví oběti na oltáři vnější část pravého ucha kandidáta na úřad a je zvykem, že se kněz během křtu dotýká ucha katechumena a pronáší slova Effetha! (otevři se), protože tímto způsobem Kristus uzdravoval neslyšící (LURKER 1989: 254-255).

V pozdější době začaly uši znamenat sídlo paměti - Plinius St. se domníval, že je jím ušní lalůček (PLINIUSZ ST. 2004: 103), který starověcí právníci pečlivě používali, když tahali za ucho vyslýchaného nebo obžalovaného - a zároveň tehdy, když pronášeli svou řeč nebo citovali právní akty, což mělo sloužit k rozpomenutí se na fakta důležitá pro vyšetřování nebo výslech svědků či obžalovaných. Jednou z primárních či dalších sankcí, nebo spíše pedagogickou a vzdělávací metodou používanou na dětech ve starověku doma i ve školách bylo tahání viníka za uši, aby si takovýto provinilec déle pamatoval svůj přestupek a trest. V současné době je to spíše způsob napomenutí žáka učitelem nebo syna otcem.

V kulturách Dálného východu — např. v Číně — masivní, dlouhé a široké ušní boltce symbolizují vědomosti/znalosti, moudrost a zdravý rozum, a dokonce nesmrtelnost. Lao-cy, pololegendární čínský filozof z 6. století př.n.l., měl údajně uši o délce sedmi palců (více než $17 \mathrm{~cm}$ ), a proto byl nazýván „dlouhé uši“. Buddhisté považují dlouhé ušní lalůčky za znamení moudrosti. V evropské tradici, tedy polské a české, dlouhé uši obrazně symbolizují přílišnou zvědavost a odposlouchávání, vměšování se a zasahování do záležitostí jiných lidí. Uši jsou také považovány za „centrum“ vyjednávání a zprostředkování, protože nasloucháním jiným lidem s nimi, i s fyzickou realitou kolem nás, navazujeme kontakt. Poslech okolního světa (toho, co je slyšitelné) a jiných lidí je mezilidským „otevřením se“, navazováním kontaktů a komunikací, které však mohou i nebezpečně směřovat $k$ podřizování se cizí vůli.

Oslí uši ${ }^{6}$ jsou signálem hlouposti, v dávných školách (nejen polských nebo českých) se špatným žákům a studentům nasazovaly na hlavu čepice s oslíma ušima nebo byli přesazováni do „oslovských lavic“. Boecké uši ${ }^{7}$ byly zase sym-

5) „Samuel všechna slova lidu vyslechl a přednesl je Hospodinu“ (Samuel 8,21); „Nakloň ke mně, Hospodine, ucha svého, a slyš řeč mou" (Žalm 17,1).

6) Ve starověké mytologii Midas, král z Phrygia, jako rozhodčí v hudebním duelu mezi Apollonem a Marsyem a Panem oznámil vítězství Marsya a předal mu cenu, což Apollona urazilo, tudíž způsobil, že Midasovi narostly oslí uši.

7) Odkaz na provincii Boiótie (ř. Boiótia), zemědělsko-pastýřskou provincii starověkého středního Řecka, jejímž 
bolem někoho mentálně omezeného nebo hudebně či rétoricky neschopného. Hluchota je opakem otevření se a známkou zvědavosti na hmotný svět. Mưže být spojována s „druhým světem“, kde je vše zřejmé a kde nejsou obyčejným smrtelníkům $\mathrm{k}$ dispozici žádné obvyklé způsoby lidské komunikace.

Zvonění v uších (stejně jako svědění, pálení, brnění a lechtání) podle lidové pověry znamená, že při zvonění $\mathbf{v}$ pravém uchu nás někdo chválí a mluví o nás jen v dobrém, naopak při zvonění v levém uchu nás někdo pomlouvá a očerňuje. V určitém prostředí se věří, že blížící se zprávy a zvěsti signalizuje zvonění v pravém uchu, naopak při zvonění v levém uchu jde o předpověd' smrti. Důležité jsou také vlastnosti uší - propíchnuté uši symbolizují obvykle otroctví a podrobení se někomu ${ }^{8}$, ale najdeme zde i výjimky - v tradici evropských námořníků bylo nošení prstenu v propíchnutém ušním lalůčku znamením zasnoubení nebo sňatku s mořem. Ve víře Hindů zase propíchnuté ušní boltce malého dítěte zajištovaly jeho zdraví a ochranu proti chorobám, což ještě posilovaly na uších zavěšené talismany.

Za zmínku stojí, že náušnice, záušnice a jiné ozdobné předměty zavěšené na ušním boltci nebo zapnuté v propíchnutém uchu, dnes nahrazované sponami, přivěsky a nálepkami, jsou nadčasovými amulety a symboly péče - ty vyrobené ze zlata byly spojovány s kultem Slunce, stříbrné zase Měsíce. Tento druh symbolické ozdoby uší, vhodného tvaru a zdobený specifickými apotropeickými vzory, byl účinný v ochraně před zlými duchy a kouzly. Pro buddhisty jsou náušnice ozdobou bódhisattvy (KOWALSKI 1998: 568-571), nebo bytosti vedené altruistickou motivací, usilující o prospěch bližních.

Během propichování dětských ušních boltců byla tekoucí krev chápána jako obět božstvu, které se mělo postarat o dítě a pečovat o jeho osud. V dávných dobách bylo na území Eurasie obvyklé nařezávání uší (poškozování ucha a způsobení vážného krvácení) při pohřebních slavnostech, jako výraz smutku. V moderní době se stalo řezání nebo stříhání uší trestem, coby připomínka dávného zvyku uvěznění nebo zajetí (otroctví). U Slovanů měly náušnice léčivé účinky, stříbrné a měděné zabraňovaly mnohým nemocem (ovlivňovaly odolnost těla), naopak zlaté ochraňovaly a zlepšovaly zrak nebo bránily jeho

\footnotetext{
hlavním městem byly Théby. Athéňané zesměšňovali její obyvatele jako údajně tupé, nevzdělané křupany, i když to byl domov mj. Hesioda, Korynny, Pindara, Plutarcha, Pelopidase a Epaminondase. Oslí uši (obrazně), což je narážka na biblické srovnání Izacharova syna Jacoba coby „silného osla“, nejsou na východě v podstatě hanlivou urážkou, poněvadž toto zvíře je velmi pracovité a užitečné $(\mathrm{Gn} 49,14)$.

8) Právo zřízené zákonem Božím stanovilo (Ex 21,1-6), že hebrejský otrok musí být propuštěn po šesti letech práce. Mohl však zůstat u svého pána/vlastníka po delší dobu. Ten pak jeho ucho propíchl šídlem, což bylo známkou otroctví až do smrti.
} 
poškození. V mnohých kulturách sloužilo ucho jako zdroj informací o jedinci; velké a špičaté uši vzbuzovaly obavy a úzkost, protože nesly démonické znaky; špičaté a odstávající nebo přiliš ochablé uši značily odlišnou a strach vyvolávající osobu, která má vazby s podsvětím (orbis exterior). Slované věřili, že lidé s velkýma ušima nadprůměrně slyší, jsou hudebně nadaní a zvědaví (vlezlí) a také rádi odposlouchávají, naopak odstávající uši byly vnímány jako známka moudrosti, malé uši charakterizovaly nebezpečné lidi. $V$ polské lidové tradici tvar uší vypovídal o detailech spojených s osudem majitele; novorozencưm s malýma ušima předpovídali brzkou smrt, znaménko na uchu prorokovalo utonutí malého dítěte.

Uši bledé a bělavé znamenaly zlého člověka s chladným srdcem, uši malé a těsně přiléhavajicí $\mathbf{k}$ hlavě byly spojovány s falešnými a lstivými lidmi se špatnou povahou. U Arabů ochlupené uši symbolizují velmi dobrý sluch, odstávající uši prozrazují cholerika nebo hlupáka.

V sexuální oblasti je symbolika ucha rovněž důležitá. Obvykle symbolizuje vagínu - slova se dostávají do našeho ucha, čímž „oplodňuji“ naši mysl nápady a inspiracemi, což se promítlo i do křestanských tradic. ${ }^{9} \mathrm{~V}$ afrických kmenech (u Mandingů a Dogonů v Súdánu) je ušní lalůček falickým symbolem, zevní zvukovod zase představuje vagínu.

Závěrem je vhodné se zmínit o uchu Dionýsově ${ }^{10}$, starobylém odposlouchávacím zařízení, obrazně řečeno předchůdci ušní trubky, tedy zastaralého naslouchacího aparátu.

Frazémy, jejichž součástí je, jako základní lexikální složka, označení smyslů a smyslových orgánů, jsou somatismy, tedy frazeologická slovní spojení týkající se lidského (zviřrecího) těla (organismu) a jeho funkcí. Polština a čeština jako příbuzné slovanské jazyky takové frazémy s bohatou historií v lexikální zásobě mají, často jsou ekvivalentní. Byly převzaty z dávných kultur a antických tradic a také $v$ dnešní době mají své využití. Tento druh frazémů je přítomen rovněž v polských a českých příslovích („moudrostech národů“) a sentencích, které tvoří „zlaté myšlenky“ nebo „okřídlená slova“. ${ }^{11}$

9) „Raduj se panno, matko Krista Pána, jenž počalas uchem!“ (lat: „Gaude, Firgo, Muter Christi, quae za aurem conceptisti“) - citát ze Salzburského misálu, dvojverší Ennodia z Pavie (Magnus Felix Ennodius), raně křestanského spisovatele a teologa, biskupa a světce katolické církve. $V$ této větě ucho znamená poslušnost Božímu slovu, souhlas k početí Mesiáše, nebot̉ naslouchání slovům Zvěstování, je přijaté Verbum (KOWALSKI 1998: 568-571).

10) Podle pověsti Dionýsius Starší, syrakuský tyran proslulý svou podezř́ivavostí, nařídil vydlabat akustický výklenek v jeskyni, aby mohl osobně odposlouchávat rozhovory vězňu pracujících v kamenolomech. Podobné odposlouchávací zařízení měl sestavit Leonardo da Vinci pro milánského knížete Lodovica Sforzu, nazývaného Moro (KOWALSKI 1998: 568-571).

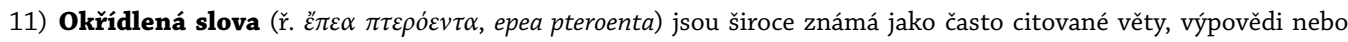


Jedná se o velmi zajímavý předmět lexikálního, frazeologického a stylistického zkoumání. Východiskem se staly klasické polské a české lexikografické práce včetně specializovaných, dvojjazyčných, frazeologických slovníků, které jsou uvedeny v seznamu literatury k tomuto článku, jmenovitě: Slovník spisovného jazyka českého, Wielki słownik języka polskiego, Slovník české frazeologie a idiomatiky (red. F. Čermák, J. Hronek), Lidová rčení J. Zaorálka, Lidské tělo v české a polské idiomatice E. Mrhačové a R. Ponczové, Słownik frazeologiczny czesko-polski H. Pietrak-Meiser, Słownik frazeologiczny czesko-polski M. Basaja a D. Rytel a také Czesko-polski słownik skrzydlatych słów T. Z. Orłoś a J. Hornik i Česko-polský frazeologický slovník $\mathrm{E}$. Mrhačové a $\mathrm{M}$. Balowského. $\mathrm{Z}$ těchto zdrojů bylo excerpováno a zařazeno do kategorií dokonce 476 českých a polských frazémů, v nichž se objevily názvy smyslů a příslušných orgánů, tedy: nos a čich [węch], kůže [skóra] a hmat [dotyk], jazyk [język] ${ }^{12}$ a chut' [smak], ucho a sluch [słuch] a také oko i zrak [wzrok]. Ty byly abecedně uspořádány (vyjma opakování), z čehož 61 (7 + 54) tvořilo lexikální strukturu, ve které lexém sluch [słuch] a ucho tvoří dominantní slova. Tímto způsobem připravený základní seznam ${ }^{13}$ byl dodatečně rozšǐřen o skupinou přísloví a „okřídlených slov“, která se pojí se zkoumanou problematikou

prohlášení, přičemž autora a okolnosti vzniku těchto výroků lze určit. Tyto věty jsou obrazné, barevné a náznakové. Okřídlená slova se zpravidla skládají z několika komponentů (obvykle jedno až čtyři slova). Sémantické pole okřídleného slova kromě vrstvy přesného významu (denotace) zahrnuje také vrstvu konotace. To znamená, že když př́jemce chce pochopit význam obsažený v okřídlených slovech v rámci kontextu výpovědi, musí dostatečně znát kulturní obsah s nimi spojený. Zdrojem okřídlených slov se mohou stát kromě jiných texty, jako jsou: 1) citace, např. biblismy (Cenniejsi jesteście niźli wróble...), citace z literatury (A. Mickiewicz: mędrca szkiełko i oko...), filmů (Seksmisja: Ciemność, widzę ciemność!), písně (The Beatles: All you need is love), výroky slavných lidí (L. Wałęsa: Nechci, ale musím...); 2) tituly a názvy, např. knihy (Paragraf 22 / Hlava 22) nebo filmy (Zezowate szczęście); 3) slogany a hesla (Reklama dźwigniq handlu!), 4) jména nebo označení fiktivních postav, použivaná namísto běžných jmen (Batman, Raskolnikov, Big Brother), 5) autorské termíny, pojmy a koncepty, např.: éra atomu, globální vesnice, princip neurčitosti. Tento název v Polsku poprvé použili na přelomu 19. a 20. století Petr Chmielowski a Tadeusz Boy-Żeleński (po vzoru Georga Büchmanna a Geflügelte Worte z roku 1864), ale stále to byla jen poetická metafora, kdy tento termín nebyl nepoužíván v moderním slova smyslu. Formulace okřídlená slova se začala šírit jako koncept a pojem na konci 50. let. Mezi polské teoretiky a badatele věnující se okřídleným slovům patřili Henryk Markiewicz (publikoval v týdeníku Przekrój sérii článků pod názvem Kdo to řekl? aneb Okřídlená slova polské literatury (Kto tak powiedział? czyli skrzydlate słowa literatury polskiej), v nichž byly zmíněny nejznámější a nejpopulárnější citace, mimo jiné z literatury, filmu, historie. Stanisław Skorupka poprvé definoval pojem jako dobře opotrebované výrazy a slovní spojení, obrazné metafory v 2. svazku Frazeologického slovníku jazyka polského (Varšava 1967-1968). V roce 1990 pak pojem použili Henryk Markiewicz a Andrzej Romanowski v dalším vydání slovníku Okřídlená slova, který obsahuje bohatý soupis známých a opakovaných citací, sloganů a názvi̊. Od této doby okřídlené slovo získalo v Polsku status termínu. V roce 1996 v krakovském nakladatelství Universitas vznikl Czesko-polski słownik skrzydlatych słów (Česko-polský slovník okřídlených slov), který vytvořily Teresa Zofia Orłoś a Joanna Hornik (MARKIEWICZ, ROMANOWSKI 1990: 5-6, 275; TARSA 1994: 102; CHLEBDA 2000: 88; CHLEBDA 2005: 15-17).

12) Tento lexém, jakož i frazémy, rčení a přísloví vytvořené s jeho pomocí byly dříve představeny v autorově článku s názvem Leksem język/jazyk w polskich i czeskich frazeologizmach występujących w przysłowiach i sentencjach (TKACZEWSKI 2014: 239-248).

13) Pro vědce nebo překladatele (tlumočníka), který připravuje takovýto seznam, je obtížné najít ekvivalent, doslovný význam/smysl určitého frazému v obou jazycích, jakož i „na obou stranách“ vhodné stylistické zařazení určité frazeologické jednotky; není to vždy možné. $Z$ tohoto důvodu se často objevují idiomy, které nelze doslova přeložit 
- lexém sluch [słuch] a jeho funkční synonymum slyšení [słyszenie] vytvořil jen jednu sentenci/přísloví, naopak výraz ucho se podílel na 5 takovýchto konstrukcích. Zajímavé statistiky se týkají proporcí všech 476 zkoumaných somatických frazémů a 24 přísloví s nimi spojených, včetně jejich kvantitativního pořadí, jak je níže uvedeno - graf č. 1 .

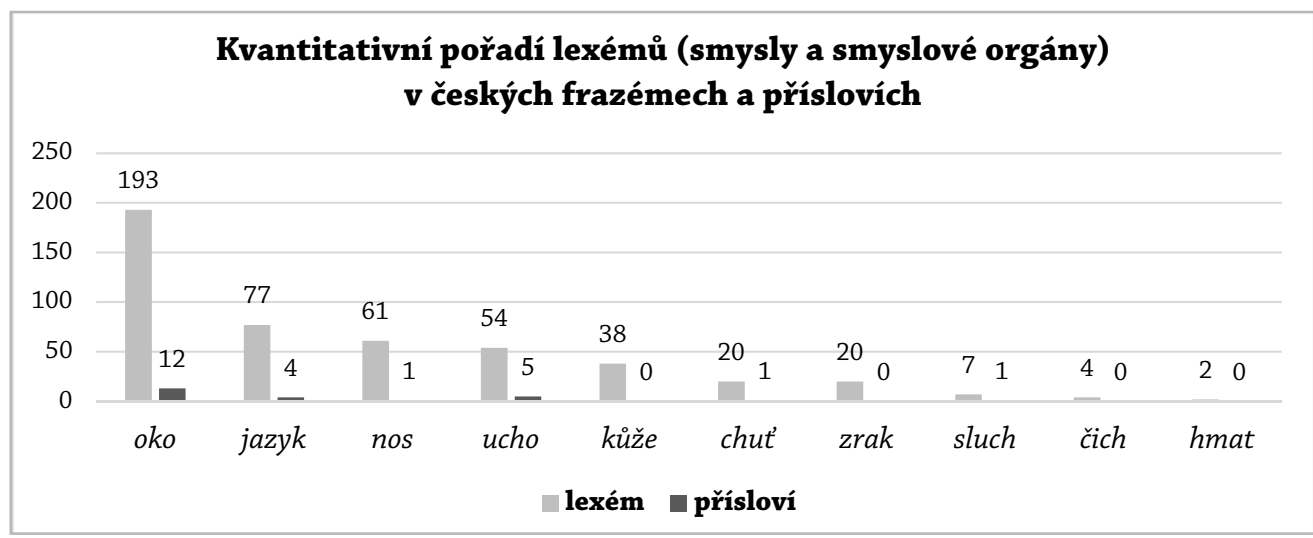

Zdroj: Vlastní zpracování

Graf č. 1

Kvantitativní pořadí lexémů (smysly a smyslové orgány) v českých frazémech a příslovích

Lexém sluch [słuch] je přítomen v 7 českých frazémech, např.:

1. • donést se k sluchu někoho [dojść do czyichś uszu / doszły słuchy], 2. • hrát podle sluchu [grać coś ze słuchu (bez nut, z pamięci)], 3. • mít dubový sluch/ dubové ucho [mieć drewniane/dębowe ucho // nie mieć słuchu], 4. • nemohu uvěřit svému sluchu [nie mogę uwierzyć własnym uszom], 5. • nenalézt / nedojít nikde sluchu [nie znaleźć nigdzie pomocnej dłoni / nie znaleźć u nikogo zrozumienia], 6. • popřát / dopráát sluchu někomu [wysłuchać kogoś], 7. • zbystřit sluch [wytężyć słuch]. Funkční synonym lexému sluch/stuch nebo slyšení/styszenie (současně s lexémem uši) vytváří pouze jedno př́ísloví: • Oči jsou k vidění a uši k slyšení. [Oczy są do patrzenia, a uszy do słyszenia. / Człowiek ma oczy i uszy, żeby patrzył i słuchał (Ev. sv. Matouše)].

Slovo ucho se objevuje dokonce v 54 českých frazémech v somatickém smyslu, např:

nebo které se v obou jazycích stylisticky neshodují. V takovém případě je možné citovaný frazém přiblížit pouze opisem. 
1. • být jedno ucho [zmięniać/zamieniać się w ucho/słuch // natężyć uszy (ucho) // słuchać czegoś z ciekawością], 2. • být mokrý za ušima [mieć mleko pod nosem], 3. • být podělaný / posraný za ušima [bardzo się bać], 4. • být (vězet / koupat se) v něčem až po uši [zabrnąć w coś aż po same uszy / utonać w czymś], 5. • dát někomu za uši // dát někomu přes uši [dać komuś po nosie // dać komuś po uszach / uderzyć kogoś], 6. • dostalo se (mu) k uším, že... [doszło do (jego) uszu, że...], 7. • dostat po uších [dostać po łapach/nosie // zostać upokorzonym], 8. • drbat se (škrábat se/poškrábat se / podrbat) (v rozpacích) za uchem (za ušima) [drapać się/skrobać się po głowie // nie wiedzieć, co począć / być zakłopotanym], 9. • je to ještě ucho/ouško [o kimś bardzo młodym, niedoświadczonym // ktoś ma jeszcze „mleko pod nosem/brodą“], 10. • jedl, až se mu dělaly boule za ušima //jedl, až mu za ušima lupalo (vrzalo/praskalo) [jadł, aż mu się uszy trzęsły // jadł żarłocznie/z apetytem], 11. • hučet někomu do uší [świdrować/wiercić komuś w uszach // namawiač kogoś długo do czegoś], 12. • lahodí to uším někoho [coś jest muzyką dla czyichś uszu // coś głaska/ pieści czyjeś uszy], 13. • mít černé za ušima [być głupim / niedoświadczonym], 14. • mít dobré ucho (pro hudbu) [mieć (dobre) ucho], 15. • mít tenké (zaječí) uši [mieć czujne ucho/uszy jak u zająca // mieć otwarte/nastawione uszy], 16. • mít oslí uši [mieć ośle uszy (o człowieku/książce)], 17. • mít uši jen pro někoho [słuchać tylko kogoś], 18. • mit uši všude [mieč otwarte/nastawione uszy], 19. • mít v uších nasráno [przestroga dla kogoś, kto nie słucha uważnie], 20. • mit za ušima [być kutym na cztery nogi // być chytrym], 21. • mluvit k hluchým uším [mówić jak do głuchego/ściany // rzucać grochem o ścianę], 22. • nasadit někomu škvora (brouka/cvrčky/červa) do ucha [zabić/wbić komuś ćwieka w łeb/głowę // podsunąć jakąś niepokojacą myśl], 23. • našpicovat / špicovat uši [postawić uszy // nadstawiać uszu], 24. • natahovat (napínat/ nastražit/nastavovat/špicovat) uši [natężyć ucho // nadstawiać ucha/ucho/ uszu], 25. • něco rve někomu uši // něco rve někoho za uši [uszy bolą/ pękają/puchną od czegoś // coś drażni czyjeś uszy], 26. • nevěřit svým/vlastním uším // sotva věřit svým uším [nie wierzyć własnym uszom // być zdziwionym], 27. - otloukat někomu něco o uši [kłaść komuś coś do ucha // nabijać czymś uszy // zawracać komuś czymś głowę], 28. • (pohrozil mu) že mu uši utrhá [(groził mu, że wytarga go za uszy)], 29.・ poslouchat na pưl ucha (jen na jedno ucho / jedním uchem) [słuchać jednym uchem], 30. • projit/prolézt/udèlat zkoušku s odřenýma ušima [ledwo coś uzyskać, zdać (np. egzamin)], 31. • pusa od ucha do uchu // mit pusu od ucha k uchu [gęba od ucha do ucha // mieć gebę od ucha do ucha], 32. • pouštět něco jedním uchem tam, druhým ven [jednym 
uchem wpuszczać, drugim wypuszczać // nieuważnie słuchać], 33. • přistrčit někde ucho [nadstawić ucha], 34. • otloukat někomu něco o uši [nabijać komuś czymś uszy], 35. • sedět si na uších [puszczać coś mimo uszu], 36. • slyšet něco na (své) vlastní uši [słyszeć coś na własne uszy], 37. • spát jen na jedno ucho [spać lekkim/płytkim snem], 38. • střihat (střihnout zastřihat) ušima [strzyc/zastrzyc uszami], 39. • svěsit/schlípnout uši [zwiesić uszy / opuścić uszy], 40. • tahá to za uši [drapie to w uszy // coś źle brzmi], 41. • ten má ale uši! [ale ten ma ucho! (o kimś, kto ma wspaniały słuch)], 42. • to není pro (tvoje/cizí) uší [to nie jest dla (twoich/obcych) uszu], 43. • umazaný/špinavý až za ušima bardzo umazany czymś/brudny], 44. • úsmèv od uchu $\boldsymbol{k}$ uchu [uśmiech od ucha do ucha], 45. • utrhnout někomu (obě) uši [oberwać komuś uszy (groźba kary)], 46. • už mě z toho brní (obě) uši! [już mnie od tego uszy bolą! // mam już dość stuchania tego], 47. • vytahat/vykrákat někoho za ucho (uši) [wytargać kogoś za uszy / ukarać kogoś bolesnym pociągnieciem za ucho], 48. • zacpat si/zacpávat si uši [zakrywać/zamykać (zasłaniać/zatykać) sobie uszy], 49. • začervenat se až po uši [zaczerwienić się po same uszy], 50. • zadlužit se (vězet v dluzích) po uši [zadłużyć się (tkwić w długach) po uszy], 51. • zamilovat se (být zamilován) až po uši [zakochać się (być zakochanym) po same uszy], 52. • zapsat/ psát si něco (naučení) za uši [zapisać sobie coś w pamięci // wbić sobie coś do głowy], 53. • zatahat někoho za uši (wytarmosić/wytargać kogoś za uszy (ukarać)], 54. • zaslechnout něco jedním uchem [obić się o uszy // przypadkiem coś usłyszeć i nie ręczyć za wiarygodność tego] a také v jednom nespisovném obratu, obrazném a „nesymetrickém“ - lexém ucho se objevuje jenom v polském frazému: (55) • dostat starou bačkoru [dostać „ucho od śledzia“ / dostać „figę z makiem“(dostać coś nieistniejącego/niemożliwego // nic nie zyskać mimo starań, ponieść stratę)].

Tento lexém se nachází pouze v 5 českých příslovích (jako somatismy), např.:

1. - (I) Stěny/zdi mívají/maji uši [(I) Ściany miewają/mają uszy]. 2. Moudré ucho nedbá na hloupé řeči [Tylko głupiec słucha oszczerstw, mądry człowiek wyrabia sobie własne zdanie]. 3. - Než se oženíš, pošli uši mezi lidi [wybierajac małżonkę, należy zwrócić uwagę na to, co mówią o niej inni]. 4. - Oči jsou k vidění a uší $\boldsymbol{k}$ slyšení [Oczy sq do patrzenia, a uszy do styszenia / Człowiek ma oczy i uszy, żeby patrzył i słuchał (Ew. św. Mateusza)]. 5. • Poslouchej uchem, ne břichem [Stuchaj uchem, a nie brzuchem] a jednou v přeneseném významu - (6) • Tak dlouho se chodí se džbánem pro vodu, až se ucho utrhne [Póty dzban wodę nosi, póki sie ucho nie urwie]. 
Při posuzování výše uvedených somatických kolokací s českými a polskými lexémy sluch [słuch] a ucho je třeba vzít na vědomí typologické rozlišení, tedy jejich vzájemnou ekvivalenci a jejich přeložitelnost. Užitečné v tomto případě by bylo typologické rozdělení Haliny Pietrak-Meiser, která tvrdí, že:

„[...] jsou považovány za ekvivalenty dvou frazémů takové idiomy, které se vyznačují stejným významem a stylistickým zbarvením. Existuje velká rozmanitost ekvivalentů, a to od totožných přes podobné až po nepřekladatelné. Tři základní skupiny tvoří 1. zcela adekvátní ekvivalenty, 2. částečně adekvátní ekvivalenty a 3. neadekvátní ekvivalenty“ (PIETRAK-MEISER 1985: 189-190).

Na základě výše uvedeného tvrzení mohou být tyto typy členěny podrobněji, viz graf č. 2:

\begin{tabular}{|c|c|c|c|c|c|c|c|c|}
\hline & & & & Frazeologic & zé ekvival & nty & & \\
\hline & $\begin{array}{l}\text { cela ade } \\
\text { ekvival }\end{array}$ & $\begin{array}{l}\text { zvátní } \\
\text { nty }\end{array}$ & $\begin{array}{r}\text { Částečn } \\
\text { ekvi }\end{array}$ & $\begin{array}{l}\text { adekvátní } \\
\text { alenty }\end{array}$ & $\begin{array}{l}\text { Neade } \\
\text { ekviv }\end{array}$ & $\begin{array}{l}\text { kvátní } \\
\text { lenty }\end{array}$ & $\begin{array}{l}\text { Aproxi } \\
\text { („zrádná slc }\end{array}$ & $\begin{array}{l}\text { anty } \\
\text { a fráze") }\end{array}$ \\
\hline $\begin{array}{l}\text { Identické } \\
\text { frazémy }\end{array}$ & $\begin{array}{l}\text { Podobné } \\
\text { frazémy }\end{array}$ & $\begin{array}{l}\text { Rozdílné } \\
\text { (diferencované) } \\
\text { frazémy }\end{array}$ & $\begin{array}{l}\text { Ekvivalenty } \\
\text { bez úplné } \\
\text { sémantické } \\
\text { totožnost }\end{array}$ & $\begin{array}{l}\text { Ekvivalenty } \\
\text { bez úplné } \\
\text { adekvátnosti } \\
\text { v gramatické } \\
\text { struktuře }\end{array}$ & $\begin{array}{l}\text { Sémantické } \\
\text { idiomy }\end{array}$ & $\begin{array}{l}\text { Gramatické } \\
\text { idiomy }\end{array}$ & $\begin{array}{c}\text { Frazeologická } \\
\text { homonyma }\end{array}$ & $\begin{array}{c}\text { Jazyková } \\
\text { homonyma }\end{array}$ \\
\hline
\end{tabular}

Zdroj: vlastní zpracování

\section{Graf č. 2}

Typologie ekvivalence českých a polských somatických frazémů

Posledním krokem byla statistická analýza sledovaných somatických frazémů (s lexémy sluch/stuch a ucho). Výpočet byl komplikován skutečností, že některé české somatismy mají v polštině několik ekvivalentů (viz popis/vysvětlení významu). $\mathrm{V}$ tomto případě jsme vzali v úvahu pouze doslovný nebo podobný význam. Během zkoumání došlo k excerpci 66 frazémů (pouze somatických ${ }^{14}$ ). Na základě důkladných výpočtů bylo rozlišeno 27 zcela adekvátních ekvivalentů, 22 částečně adekvátních ekvivalentů, 14 neadekvátních ekvivalentů a 3 aproximanty („zrádná slova / fráze“), což je graficky znázorněno v následujícím grafu č. 3 .

Z analýzy výše uvedených a charakterizovaných dokladů vyplývá, že somatické idiomy s názvy smyslů a smyslových orgánů (v tomto případě sluchu [słuch] a ucha) jsou jevy sémanticky nejednoznačné. Lexikální ekvivalence těchto struktur je často sporná a kontroverzní, což přispívá $\mathrm{k}$ neúplné, často nevyjádřené

14) Ve skupině prozkoumaných frazémů se objevily dvě nesomatické jednotky, případně jednotky o nejisté charakteristice: „Tak dlouho se chodí se džbánem pro vodu, až se ucho utrhne“ a „dostat starou bačkoru“ [dostać „ucho od śledzia“]. 
a intuitivní česko-polské a polsko-české přeložitelnosti (ekvivalence). Coby ilustrace daných obtíží a jako příklady takovýchto frazémů (idiomů) poslouží somatismy: • být mokrý za ušima [mieć mleko pod nosem], • dostat po uších [dostać po łapach/nosie // zostać upokorzonym], • je to ještě ucho/ouško [o kimś bardzo młodym, niedoświadczonym // ktoś ma jeszcze „mleko pod nosem/ broda "], • mít černé za ušima [być głupim / niedoświadczonym], • mít za ušima ${ }^{15}$ [być kutym na cztery nogi // być chytrym], • dostat starou bačkoru [dostać „ucho od śledzia“ / dostać „fige z makiem“ (dostać coś nieistniejącego/niemożliwego // nic nie zyskać mimo starań, ponieść stratę)] atp.

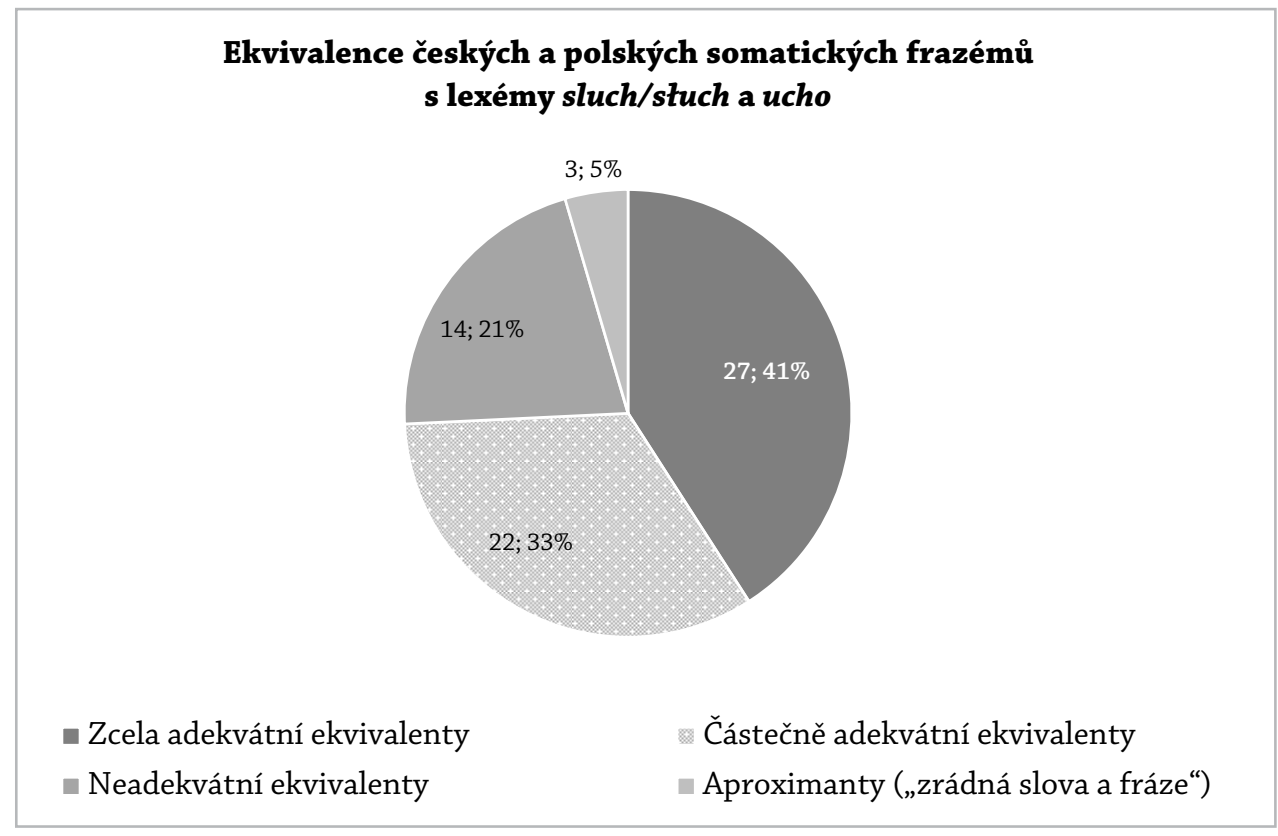

Zdroj: vlastní výpočty

Graf č. 3

Ekvivalence českých a polských somatismů s lexémy sluch/słuch a ucho

Závěrem: $V$ této studii jsme chtěli upozornit na specifický typ frazémů využívajících výrazy související se smyslovým vnímáním, konkrétně sluchem, a to na českém a polském jazykovém materiálu. Na kulturně-historickém pozadí jejich vzniku jsme se nejprve zabývali jejich frekvenčními charakteristikami, a to $\mathrm{z}$ hlediska všech somatismů, a následně jsme se zaměřili na problematiku jejich překladové ekvivalence. Z analýzy vyplynulo, že somatické idiomy s výrazy stuch

15) Český somatismus mit za ušima [polský překlad (doslova): mieć za uszami] má v polštině jiný význam: mieć nieczyste sumienie // mieć grzechy na sumieniu // mieć grzesznq przeszłość nebo być niezłym „gagatkiem“(D. T.). 
a ucho jsou sémanticky nejednoznačné, v překladu se realizují formou neúplné nebo intuitivní ekvivalence. Výsledky statistického vyhodnocení představují první krok k další analýze, která by se měla zaměřit na konkrétní překladové texty a jejich vzájemné srovnání. Tomu bychom se rádi věnovali v další etapě našeho výzkumu.

\section{LITERATURA}

BASAJ, Mieczysław, RYTEL Danuta

1981 Stownik frazeologiczny czesko-polski (Katowice: UŚ)

BOWIE, Fiona

2008 Antropologie náboženství (Praha: Portál)

CHLEBDA, Wojciech

2000 „Król bywa nagi. Między cytatem a skrzydlatym słowem“, in Annales Universitatis Mariae CurieSkłodowska, Sectio FF Philologiae, t. XVIII (Lublin: Wyd. UMCS)

2005 Szkice o skrzydlatych stowach. Interpretacje lingwistyczne (Opole: Wyd. UO).

Czesko-polski słownik zdradliwych wyrazów i pułapek frazeologicznych. Orłoś, Teresa, Zofia (red.) (Kraków: Wyd. UJ), 2006

Encyklopedia językoznawstwa ogólnego. Polański, Kazimierz (red.) (Wrocław: Ossolineum), 1999

KOPALIŃSKI, Władysław

2006 Stownik symboli (Warszawa: OW RYTM)

KOWALSKI, Piotr

1998 Leksykon: znaki świata. Omen, przesad, znaczenie (Warszawa: WN PWN)

LURKER, Manfred

1989 Stownik obrazów i symboli biblijnych (Poznań: Wyd. Pallottinum)

MARKIEWICZ, Henryk, ROMANOWSKI, Andrzej

1990 Skrzydlate stowa (Warszawa: PIW)

MRHAČOVÁ, Eva, BALOWSKI, Mieczysław

2009 Česko-polský frazeologický slovník (Ostrava: FF OU)

MRHAČOVÁ Eva, PONCZOVÁ, Renáta

2004 Lidské tělo v české a polské idiomatice (Ostrava: Tília) 
Dariusz Tkaczewski

Symbolika v českých a polských somatických frazémech s lexémy sluch/słuch a ucho ...

ORŁOŚ, Teresa, Zofia, HORNIK, Joanna

1996 Czesko-polski słownik skrzydlatych słów (Kraków: TAiWPN „Universitas”)

ORŁOŚ, Teresa, Zofia

2005 Studia z frazeologii czeskiej i polskiej (Kraków: Wyd. UJ)

PIETRAK-MEISER, Halina

1985 Czeskie wyrażenia i zwroty frazeologiczne na tle porównawczym polskim (Lublin: Wyd. KUL)

1993 Stownik frazeologiczny czesko-polski (Lublin: Wyd. KUL)

PLINIUSZ ST.

2004 Historia naturalna (Wrocław: Ossolineum, De Agostini Polska)

RIPA, Cesare

2013 Ikonologia (Kraków: TAiWPN „Universitas”)

SKORUPKA, Stanisław

1949 „Przenośnie w języku potocznym”, Poradnik Językowy, z. 1, 1949, s. 5-14; z. 2, s. 5-11

Slovník české frazeologie a idiomatiky. František Čermák, Jiří Hronek (red.) (Praha: Academia), 1994.

Slovník spisovného jazyka českého, http://ssjc.ujc.cas.cz

TARSA, Jadwiga

1994 „Dyskretny urok nagłówka, czyli skrzydlate słowa na łamach dzisiejszej prasy“, in Zeszyty Naukowe WSP w Opolu, Filologia Rosyjska, z. 33 (Opole: wyd. WSP), s. 102

TKACZEWSKI, Dariusz

2014 „Leksem język/jazyk w polskich i czeskich frazeologizmach występujących w przysłowiach i sentencjach”, in Mrhačová, Eva, Muryc, Jiří, Kolberová, Urszula (red.), Parémie národů slovanských VII (Ostrava: FF OU), s. 239-28.

Wielki słownikjęzyka polskiego, http://wsjp.pl

ZAORÁLEK, Jaroslav

1947 Lidová rčení (Praha: Fr. Borový)

Dr hab. Dariusz Tkaczewski, Ph.D., dariusz.tkaczewski@us.edu.pl, Instytut Filologii Słowiańskiej [Ústav slovanské filologie], Wydział Filologiczny Uniwersytetu Ślaskiego w Katowicach [Filologická fakulta Slezské univerzity v Katowicích] / Institute of Slavic Studies, Faculty of Filology, University of Silesia, Poland 